\title{
Regional Charisma: The Making of a Student Leader in a Himalayan Hill Town
}

Leah Koskimaki

\section{(2) OpenEdition}

Electronic version

URL: http://journals.openedition.org/samaj/6503

DOI: $10.4000 /$ samaj.6503

ISSN: $1960-6060$

\section{Publisher}

Association pour la recherche sur l'Asie du Sud (ARAS)

\section{Electronic reference}

Leah Koskimaki, «Regional Charisma: The Making of a Student Leader in a Himalayan Hill Town », South Asia Multidisciplinary Academic Journal [Online], 22 | 2019, Online since 01 December 2019, connection on 10 July 2020. URL : http://journals.openedition.org/samaj/6503 ; DOI : https://doi.org/ 10.4000/samaj.6503

This text was automatically generated on 10 July 2020 .

\section{c) (†) $९$}

This work is licensed under a Creative Commons Attribution-NonCommercial-NoDerivatives 4.0 International License. 


\title{
Regional Charisma: The Making of a Student Leader in a Himalayan Hill Town
}

\author{
Leah Koskimaki
}

1 The main thoroughfare in Nainital, a small 'hill town' in Uttarakhand, India, is a place for strolling, gathering, protesting, and being seen. Locally referred to as the "Mall Road," it serves as the main conduit through the busy side of the town's central lake and is lined with various levels of out-facing hotels, homes, restaurants and shops built up against each other in a long row. ${ }^{1}$ Many small and cozy eateries serve as college haunts, where students from the local Kumaun University congregate in the afternoons to meet over snacks and tea. Various student leaders also would gather there to meet with friends and supporters, or to network with local activists who were protesting unemployment woes or other concerns facing local youth.

One afternoon, I was hanging out in one of these small restaurants with "Mahendra," a member of Kumaun University's DSB campus ${ }^{2}$ student union. I had arrived in Nainital after his electoral campaign, and so we began chatting about his success. "When we went for nomination in the morning, there was a large procession. They put māla (garlands) around my neck, and the guys hoisted me up and carried me around on their shoulders," he narrated with earnest pride. He particularly emphasized his style as a leader: "Here leaders don't wear suits, we wear white-colored (khadi) kurta-pajama." He said that his supporters were chanting: Mahendra nahīm - ye āmdhì hai! DSB kā Gandhi hai! [He's not Mahendra-he's a storm! He's the Gandhi of DSB Campus!]. Confirming that they were referring to him, a nascent youth politician, as India's iconic leader of national freedom and self-sufficiency, he explained:

Yes, DSB is our college and Mahendra is not a māmūli vyaktī (ordinary person). They made me Gandhiji, Mahatma Gandhi. It was out of their unkā pyār thā (affection). They felt that, 'Hamārā netā sab se acchā hai' (Our leader is the best). They were trying to impress the other students. 
Then my slogan was, 'My Pepsi Cola and Mirinda is Mahendra. My Abhishek

Bachchan is Mahendra. My Hrithik Roshan ${ }^{3}$ is Mahendra'...[pausing]

You know Abhishek Bachchan? He's a film star.

This lighthearted scene offers a glimpse into the kinds of ways that student leaders in post statehood Uttarakhand drew from various symbols and styles to produce stories and narratives of their political lives. In such spaces, Mahendra seemed to find it natural to represent himself simultaneously through the image of Mahatma Gandhi, the promoter of home-spun khadi cloth, and Bollywood actors who promote multinational branded soft drinks like Pepsi. ${ }^{4}$ After all, the famous people to whom he compared himself were all 'heroes' and personalities that could add fame and respect to his campaign. Pictures of these Bollywood film stars adorn the ubiquitous faded name placards of roadside food stalls in the hills, usually wearing "modern" attire such as sunglasses and designer jeans, showing off their worked-out bodies while drinking these beverages. Conversely, Mahendra's style of dressing up in white kurta pajama during the election was the chosen Gandhian attire of political leaders. Despite its recent association with corruption, white khadi could convey his commitment to service and add an aura of experience and legitimacy to his intentions, while signaling a very Indian and yet regional history of anticolonial protest. His slogans reveal the seeming contradictions with which young people in the region grapple: consumption and austerity, corruption and authenticity, and national and regional affiliation. In untangling this seeming pastiche of representations, this article argues that the making of youth and student leaders in the visible political aesthetics of post-statehood Uttarakhand involved the cultivation of regional charisma.

3 Throughout the following sections, I delineate the ways that student leaders in Uttarakhand, in particular forward caste Hindu Pahari ${ }^{5}$ young men, attempted to cultivate this regional charisma: through performing their know-how and connections to the town and the environment, demonstrating their moral character and sacrifices, drawing on attachments and legacies of place, and connecting with political genealogies. In a region with comparatively limited financial resources, even successful everyday brokerage and forms of clientelism were not enough to secure one's position on the political scene, and so such practices often were sutured in charismatic performances. Mahendra and other aspiring political youth embedded such attempts at generating charisma in long fought regional struggles, such as the movement for Uttarakhand statehood and aspirations for "development."

\section{Political Lives in a Mountain Region}

Situated in the Western Himalayan region, Uttarakhand became a new state in India in November 2000 and has a legacy of regional assertion. The largely forested, mountainous and rural region is known in India for its history of peasant movements (Guha 2000) particularly the popular movement against deforestation known as "Chipko" (Mawdsley 1998). A history of anti-colonial mobilization (Pathak 1997) in which young people in the region were also called to join political action (Koskimaki 2016) has shaped activism in the state. This regionalist politics drew from enduring narratives and stereotypes of the hills as a place of honesty, purity and simplicity versus the plains as more combative and corrupt (Moller 2000), as well as tropes of a Pahari (person from the hills or mountains) identification with nature (Linkenbach 
2006). This perceived dichotomy has partly acerbated grievances around the lack of progress in development, especially in the rural areas of the region as compared to many parts of India, with the blame often laid on the ignorance and apathy of plainsbased politicians (Mathur 2015). Popular descriptions of Uttarakhand as a "sacred territory" (Tillin 2013) and pilgrimage place for Hindus has sustained a growing "regional Hindutva" (Joshi 2018), which has recently become increasingly majoritarian and exclusionary. In contemporary Uttarakhand, despite women having taken on a large role in environmental and other social movements over its history (Gururani 2014), men have often dominated a visible, street-based youth politics (see also Lukose 2009). A masculine development ethos (Koskimaki 2017) has in part influenced the narrative of regionalist demands around youth futures.

The idea of Uttarakhand statehood, which one generation of students imagined in the 1970s and the next generation fought for in the 1990s, evolved out of a feeling of spatial marginalization and neglect (Mawdsley 1999; Kumar 2000; Rangan 1996, 2000; Fiol 2013). Student politics increased in the early 1970s, after a demand pushed the state to form Garhwal and Kumaun Universities, representing the districts in the west and east of Uttarakhand respectively. In the 1990s, regional youth protested the implementation of reservations for $\mathrm{OBCs}$ (Other Backward Castes), which constituted a small percentage of the population in the hills compared to the state of Uttar Pradesh of which the region once was a part. Much of this protest involved youth from large regional Rajput and Brahmin groups who were relatively less wealthy and lacked the cultural capital of their plains-based counterparts. The regional memory and news reports of students and women protesting and demanding a new state, only to face violence at the hands of police (Kumar 2011), did little to build the public trust of administrative and state machinery. The post statehood generation was both haunted and inspired by the way the past has been imagined in present politics (Sivaramakrishnan 1995:32), and locals have continued to lack faith in the developmental state (Mathur 2016) and national politicians.

6 Uttarakhand is also home to many small Himalayan "hill towns" which the British either established or further developed during the colonial period. Like most of these towns, Nainital itself had a small population (of around only 40,000 in the 2001 census). As part of a historical legacy of paternalistic colonial governance, the British developed hill stations with their cooler climates as places of recuperation, holiday-making, and summer administration. In the towns power was spatialized, with regulations about who can travel where, the "Mall Road" being a prominent feature (Pradhan 2017). Further, those residing in hill towns experience what Mathur (2015) calls "everyday narratives of remoteness" (p.390), their spaces seen as "backward" and "inferior" (p. 368). Drawing from De Certeau (1988), she refers to "place as an ordering of elements in a relationship of coexistence with each other and space as 'a practiced place" (2015:367).

7 The intimacy and history of towns such as Nainital produced a political scene quite different than that of some of India's larger cities. Professors, writers, journalists, activists and historians in Nainital often referred to regional legacies and spaces in conversation, print or speech, with affection. I found a flourishing activist print culture and journalism in the town, such as Hindi language books on local freedom fighters and regional ecologies, as well as magazines with photographs of mountain and rural scenes, alongside articles that critiqued senior politicians. Buildings, such as an old 
wooden library on Mall Road or the leafy university campus, had an aesthetic and affective presence. Student leaders would campaign in the popular flats area near the market at the end of the lake, and youth hosted small rallies at the colonial era District Collectorate, at the end of the Mall Road, or at Shailey Hall, another popular assembly place for earlier generations of activists. These off-campus places of doing politics tapped into the small hill town rhythms of life and ensured greater visibility. Mahendra and other leaders kept off-campus offices within the market place or up along the winding roads and small houses. In this way, the account of student politics in this paper is less about the campus, and more about how student leaders work to generate charisma as they move in and inhabit the political spaces of the towns themselves. Youth leaders of different affiliations were known figures in the towns, often engaging in political rallies or meeting people, while continually being reported on in well-read vernacular editions of local newspapers.

Further, regional towns were spaces of mobility and connectivity for those who left their villages for something bigger or for those who returned because they said they could not "make it" in the cities. Youth out-migration in search of employment has led to an "emptying" of the region's villages (Mamgain and Reddy 2016). Yet these mobilities have added to a "reconfiguration" of an "ecological sense of place" in Uttarakhand (Joshi 2015:20). Dyson (2018) describes young men's fascination and spiritual engagement as returnees to their mountain village in Uttarakhand, despite being changed by urban experiences. Such "rural imaginaries" have figured into hill town youth publics, with references in speeches and conversation to difficulties of village life in the hills and to dangers of travel within the mountains (Koskimaki 2011). In rallies I attended, youths conjured up metaphors such as linking the Ganges River (whose glacial source is found in Uttarakhand) to the fruits of development as flowing, along with regional youth, out of the state. Because hill towns in India are spatially "removed" from the urbanized spaces of commodity flows, although youth often migrated out for employment, their aspirations were often constrained by their inability to grapple with multiple worlds (Brown, Scrase and Ganguly-Scrase 2017). A feeling of "relational vulnerability" in Uttarakhand (Chakraborty 2018) has left mobile youth in states of constant transition. Many who travelled from rural areas to the towns in the region had to manage various strategic repertoires to signal either their "rural" or "urban" identities (Deuchar 2019). On regional university campuses, I encountered many students who returned or remained in Uttarakhand because they longed for the familiarity of life in the hills. This spectre of mobility for youth-of experiencing outside worlds, while still proving one's "embeddedness" (Verstappen 2017) in the region-has produced a fertile field for the entry of young politicians who can act as guides for others of their generation looking to improve their prospects, but yet who want to stay connected to their home. Mahendra and others often claimed that they would "take me" to a particular village or rural area and "show me" how people live in a "simple" and beautiful way there and yet how they "struggle." Student politics in towns like Nainital can be read within these regional idioms and aspirations.

\section{Aspirational Youth Politics}

9 The narratives of student politics I present here were taken from a total of 18 months of research living in Uttarakhand between 2004-2007 as part of a broader ethnographic 
and historical project on regional youth publics and development politics. At this time, on the cusp of social media use in the region, I socialized with young people who had less access to and thus were barely yet active on what were newly emerging forums such as Facebook. Rather, they were very engaged in street rallies, face-to-face meetings in organization offices, and political print production. ${ }^{6}$ I situated my examination of youth politics within larger narratives around development in the region, and the largely unfulfilled expectations after the achievement of statehood in 2000. One focus was on masculinities and how forward caste young men in the region politicized and imagined their futures.

10 While student leaders in Uttarakhand did at times engage in "muscular politics" (i.e. Michelutti 2010, 2013) and fights broke out between groups, politics in post-statehood Uttarakhand as I witnessed it was a provincial and less extravagant affair. Youth political action was less "violent" and less openly embedded in party political influence than those in other accounts from South Asia (Suykens 2018; Kumar 2012; Ruud 2010). often, student politics was also "entangled" in town and state aspirations (Kumar 2012). As many young people in Uttarakhand were unemployed, student leaders used waiting and "time pass" (Jeffrey 2010a), or rather what Andersen (2016:421) refers to as "time-use" in shaping their political futures, which he argues were "intimately entangled with aspirations, morality and conduct." Student leaders drew on tropes of sacrifice, sangarsh (struggle) and social service in conversation and protest (see also Jeffrey and Dyson 2014; Piliavsky 2014; Ruud and Price 2010; Krishna 2003; Skaria 2002). I found similarities to Suykens's (2018) observation of Bangladeshi student politics, where "risk and self-sacrifice are two central and related performative repertoires deployed to build authority within student hierarchies" (p.886). Many youths in hill towns often oriented such sacrifices to counter the negative reputation of politics as corrupt (see Jeffrey and Dyson 2014). They aligned themselves with youthfulness as innocence, creating scenes of engagement through "disagreement" (Rancière 1999, 2004), and claiming spaces of recognition and political expression. In what Jeffrey (2010b) has also described as a "contradictory youth politics," the ambiguous or liminal (Mannheim, 1972 [1936]) position of having not yet reached adulthood allowed youth to navigate and manipulate a negative reputation of state politics. ${ }^{7}$ Snellinger (2016) has articulated this position for youth in Nepal as they orient their hopes through what she calls a political mode of being as a "subjunctive as-if." This youthfulness animated their new regional and charismatic representations. As "youth" is a cultural constructed temporality (Bucholtz 2002; Durham 2004), here I refer to unemployed and unmarried young men in the regional context. Their experience of a protracted stage of youth both limited and opened up political possibilities. Unlike the political socialization that takes place largely on campuses at urban institutions such as JNU (Martelli and Ari 2018), Nainital's DSB campus was merely an extension of the town; much of political life took place off campus and in association with regional aspirations.

11 During this time as a relatively new state, some leaders were affiliated with student groups that had national counterparts, yet most groups at the time also made a point to publicly stress their "independence." For example, members of the Akhil Bharatiya Vishwa Parishad (ABVP), a Hindu nationalist student organization that has been associated with the BJP (Bharatiya Janata Party), asserted to me during a meeting in their Almora office that even if "ideologically" youth "stand together" with certain national parties, "the youth should be united on the matters related to youth." Another 
ABVP leader then also spoke out, generating nods of consensus from his friends, that "there is no need for the political parties to be involved directly in the matters of youth." Similarly, leaders from an organization (that I will keep anonymous here), which had some ties to the ideologies of CPI-ML (The Communist Party of India, Marxist-Leninist), tended to focus more on their political goals such as assisting with development and awareness in the rural and mountain regions, than on party politics. One leader from a ST (Scheduled Tribe) background, who was popular and charismatic within the organization (his charismatic representation resonated largely within his left-leaning group which fought more strongly against caste inequalities), kept a low profile in the town due to his potentially politically sensitive mobilization in more remote regions. He asserted that the fight they had to wage was against "administrative" structures, and that their real work was in raising public awareness. In contrast, members of NSUI, the National Student Union of India, claimed to me during an event in a small town in Garhwal, that they openly did work to support the Congress Party, which was in power at the time of this research. An NSUI leader claimed that other groups deny their affiliations but "secretly" support the parties behind the scenes. Mahendra protested the policies of the Congress Party but did not at all affiliate with the ABVP or Communist student organizations. He participated in rallies where youth decried political parties as corrupt, even regional political parties. His speeches focused on alleviating the region's suffering and expressed the need for youth to "unite" to fight a "system" that suppressed their future potential. However, this show of independence did not always persist into "adulthood," as many matured into supporting political parties later on.

This need for secrecy regarding party support and assertions of independence grew out of a vocalized mistrust of political parties and "adult politics" as corrupt and selfinterested. To fashion oneself as a student leader also often involved showing one's ability to work for all regional youth. Off campus rallies that I attended often attracted a gathering of youth from even opposing groups, where they would make common demands for better regional vikās (development) and unnati (progress)-meaning facilities, education, loans and employment-while expressing "anti-Western" sentiments. This article largely examines the narratives and political engagement of Mahendra and his group of forward caste young male companions from the student union who associated with each other and others from previous generations of youth protest and who traveled to nearby towns to participate in rallies and mobilize other youth in protest of the lack of development and employment in the region.

\section{Regional Charisma}

Charisma as a political and social descriptor became prominent with the work of Max Weber ([1919]2009), who argued that legitimacy to power-or domination-came in different forms, one being that of charismatic leaders who inspire "devotion" not "by virtue of ...statute," but because people "believe" in them (p.79). A charismatic leader is thus one who possesses an "extraordinary and personal gift of grace" and "heroism," and who was traditionally a "magician" and a "prophet" (p.79-80). Symbolic power and social influence can produce charisma (Geertz 2000); recalling the affective ways devotion and power can manifest, Geertz aptly describes charisma as "an abiding, if combustible, aspect of social life that occasionally bursts into open flame" (p.123). 
Charisma can animate leaders of various intentions and orientations as they generate support and trust and has been gendered and associated with "strong men"8 or a "politics of manhood" (Khadir 2012:363). Michelutti (2013) elaborates the notion of "muscular charisma" to describe physical dominance and an ability to mobilize violence.

But charisma is also a performative and place-specific quality, through which youth leaders can craft their self-image and creatively mobilize support. In Uttarakhand, regional charisma is cultivated through what Terlouw (2010) has described as the "charisma of space" and its temporal orientations-from pilgrimage sites of the past to the future imaginings of a place-as a way to produce legitimacy (p.339). My discussion thus builds on what Hansen and Verkaaik (2008) refer to as "urban charisma," for which they elaborate two aspects: charisma of the city, which "imbues its physical sites and objects, and thus the people who live in them, with unique capabilities and even magical forms of agency"; and charisma in the city, which "rests on special forms of knowledge, networks, connectedness, courage and daring" of individuals who can "reinterpret and re-enact" the city's "reservoir of myth and narrative" (p.9). Their work revises older static notions that viewed charisma as a "vaguely magical power of presence, style, seduction and performance"; charisma, they assert, has been "democratized" and is "now a widely marketed and desired object of self-making, within the reach of those with sufficient skill and purchasing power" (p.6). As described in the previous section, the hill towns provided a scene for youth politicians to play out their skills and demonstrate their connection to the region in stylized ways. Rather than refer to charisma as a natural gift, I show how it is generated through the relationship of youth to the region and its potent places.

Charisma is also gendered, caste and class inflected, and generational as continual hierarchies and authorities are built and reformed based on regional belongings and associations. I follow Gorringe's (2005) critique of an over-emphasis on charisma itself; he argues that such power must be "legitimated socially" and continually produced, and attention must be paid to other social complexities such as caste and various "cultural precedents" in the making of both leaders as well as supporters (Gorringe 2012:122). Who can actively generate charisma and who cannot access the elements that comprise this so-called magical quality? While young men and women of various caste/class and religious backgrounds participated in student politics throughout the state, and indeed generated various aspects of charismatic fashioning, here I focus on the production of charisma amongst forward caste Pahari men, who often mobilized familial affiliations to demonstrate their regional political legacies. Forbess and Michelutti (2013) and (Michelutti 2017:236) have alluded to such attributions as "divine kinship" or "divine ancestors" as potential sources of charismatic affect for revolutionaries, comrades and patrons. In the case of Uttarakhand, I borrow this term to point to the animating role of the political legacies of associates, friends and family members. In addition to drawing on such affiliations, charisma often also required leaders to show one's achievements (see also Michelutti 2018).

Charisma has to be continually maintained, drawing on multiple reterritorialized reservoirs and registers of style. I recall a student leader in Ranikhet, from a landowning Rajput family who did not affiliate with any political party, telling me how he would watch Fidel Castro give speeches on television. He expressed that he aspired to speak and influence a crowd of people in the same way. A charismatic leader might be 
seen as a "hero," recalling an earlier generational emphasis on a "spirit of sacrifice" or contemporarily idealized as "jugaadis" (those who could improvise to get things done or make things work) (Kumar 2017:327, 328). In Uttarakhand, to be seen as a "hero" might encapsulate both these ideals as student leaders work to build their charismatic affect through their accomplishments and affirmations of local style, often in "antiWesternized" tropes. While political backgrounds might influence variants in leaders' choices, one similarity that I found was the emphasis on simplicity. Spending time with ABVP members in their small and modest office, for example, one young man asserted to me that "if someone walks in the market wearing Indian kurta-pyjama, then some people may call him of purane vichär (old-fashioned), but if he walks in the same market wearing jeans, $t$-shirt and tie, or coat and pant, then the same people will say that 'he is looking like a hero." He complained, "the word hero should be used for brave men... Actually, that person is weak. Say what you like, but it is a fact that all such acts are tricks of foreign powers..."

17 This quote shows the conflicting feelings around style and presentation; In my everyday conversations, many young people in the region expressed distrust or even seemed to insecurely mock show-offs and overly urbanized types, such as tourists from the plains with their "flashy" attire. To be charismatic in the hills manifested not through a "prestige economy" (Fuh 2012), but rather through simplicity and "ethical self-making" (Chandra and Majumder 2013). Martelli (under review) has interestingly written on the austere self-fashioning of left politicians at JNU in Delhi, who downplayed their privilege as a way to represent authenticity. In Uttarakhand, many young people also made a point to maintain simplicity. I found their demeanor to follow a style similar to what Rudolph and Rudolph (1967) have described as the "traditional roots" of Gandhi's charisma- self-confidence, use of restraint, control over one's environment, and moral idealism (p.199).

18 This leads us back into a discussion of khadi in student politics. Use of homespun cotton can signify ideals of purity, sacrifice and devotion to the nation (Trivedi 2007). Yet the choice of khadi has been referred to "a particular semiotic of corruption" and "as the uniform of the rogue" (Chakrabarty 2001:52,53), the corruption of the very ideals it was meant to represent (Tarlo 1996; Mazzarella 2010). Such assertions illuminate the negative associations with politics that young people work to overcome, and Mahendra used khadi as rather a semiotic of resistance, allowing him the ironic legitimacy of "experience" through political traditions of attire. He drew from the regional traditions of Gandhian politics and anti-colonial struggle. Furthermore, local environmental activists and intellectuals often wore khadi as a commitment to sustainable development and social service (see Klenk 2010). In this way, student leaders localized their performances and styled themselves by identifying with regional political idioms.

\section{The Making of a Regional Student Leader}

Mahendra was talented and energetic and knew how to place himself in Nainital. When I first met him, he was participating at the rally for unemployed youth at an administrative building above the Mall Road. There, he had been associating himself with a previous generation of student activists from the 1990s demand for statehood. That day Mahendra arrived wearing not the kurta pajama of his campaign, but an 
oversized sport coat with a simple formal shirt. He could be seen preparing the press release for that day's protest and directing young men where to sit. Mahendra and others gave speeches to the eager group, critiquing the current leaders of the Congress Party and decrying corruption. "Our fight is with the system. We want to say to the government that the state of Uttarakhand has come into existence because of the sentiments and the feelings of the people, and we should be provided with our rights in this state," he implored. Afterwards I congregated with him and other energized leaders in a crowded tea stall. Mahendra sat in the center and other youth crowded around him to see what he was doing. A supporter commented to me that he was speaking on the "right issues" and that he liked him because he was "common" and "simple." His speech had "energy" too, he said.

But Mahendra did not always have such popularity, and at times failed at being a "naturally" charismatic leader. In Nainital he was also initially unconvincing in his identity as a Pahari. He was not born in the foothills, but rather grew up in a town in Uttarakhand's plains areas near the southern border of the state. Grappling with contradictions, he tried to separate his image from that of muscular politics, which was associated with life in plains towns and cities, yet he realized that he had to show himself a strong leader. He conveyed:

When I fought the presidential election, I lost two times. People said, 'He is bahār kā (an outsider) he is from the plains, he is badmāśs (a scoundrel).' My opponent was spreading this story to distort my image so that I'd lose. He claimed that I have people with guns and weapons...But when I showed up, they all said, 'He is not a gund̄a (villain/criminal), he is a baccā (kid).' [pause] Well, I agree that I scared some people to win the election. You know, it's an election after all. You have to do such things to win... There was a student who was opposing me. I warned him not to, otherwise he would be in trouble. He was terrified. He said, 'Bhaiya (Brother), no problem! I'll go back home.' I said, 'Don't go home, cast your vote! But don't spread bad news about me.'

This likely-embellished tale of bravery led me to ask for more details as to why people thought he was a badmāś (scoundrel). "What have you done?" I asked. "Nothing, really," he insisted. Rather he felt that he needed to show his strength and fight against those wanting to tarnish his image. As described earlier, within the stereotypes of the plains versus the hills, "outsiders" are said to bring exploitative elements into the hill region that is characterized as peaceful, pristine, and honest. Even though he was from Uttarakhand, he did not grow up in the mountainous areas which were the source of identity and mobilization around the statehood movement.

But Mahendra had a Pahari name and a political legacy which he referenced at times to others; he proudly talked about being from a Rajput family with a tradition of anticolonial activism. His grandfather was a freedom fighter during colonial rule, and Mahendra still held onto his document collection, such as Indira Gandhi's letters when she was Prime Minister, and his tamra-patra (literally a copper plaque) that the government gave those who had honorably fought for India's independence from British rule. He once asked out loud to me, as if demonstrating his grandfather's sacrifice, "How did he work? This time we have vehicles, but at that time they used to walk 60 kilometers to Almora! He went to jail many times-sometimes for 6 months." The neighborhood ("colony") of Mahendra's family home was "full of freedom fighters" because the government allotted them land there after Independence. 

came and fought in the student election, he went on a hunger strike in a demand to open more positions for students seeking admission. He narrated to me:

\begin{abstract}
No one knew me in those days... There were a lot of problems concerning university admissions. Many students were left behind who wanted to study but could not... When we started our protest, we wrote a letter to the college administration, but they refused...It was Friday when we planned to start our protest. All the other leaders insisted that since Sunday is holiday, that we should come on Monday. But I decided to start on Saturday! I stopped eating and drinking. I went on a hunger-strike on the campus. And all students who could not get admission joined and supported me.
\end{abstract}

He was able to meet with the college administration, and recalled, "Everyone got admission, and I became their favorite! After that, a lot of things happened. Some gunda (gangsters) came and destroyed our posters... But then people started to really like me. They felt that, "This guy can do something for us."'

I attended multiple rallies where Mahendra gave speeches in Nainital and nearby towns. During one rally in the neighboring town of Bhowali, he dressed in simple, ironed clothes, such as a knit sweater and buttoned formal shirt, with his hair combed smoothly. Standing in the town's central market, he addressed the crowd over the incessant honking of passing cars, speaking very quickly and emphatically in a Pahariinflected Hindi, referring to the youth in the crowd as "brothers." He again applauded the role of youth in the movement for statehood and lamented that regional schemes for youth loans and employment had failed to have an effect. Older Pahari men in khadi and white Gandhi caps, women passing through the market, and a large crowd of youth stopped to listen to his speech. The young men especially clapped and cheered him.

Mahendra had to learn how to navigate this political terrain and engaged in his locality by gaining visibility. Drawing from his youth and assumed "innocence," he wanted to gain people's trust. He was, in his terms, "just a kid." Yet he tried to demonstrate a certain "toughness" to win elections and supporters. Even when recalling the story of his election to me, he seemed careful to project a self-image as a tough yet discerning leader.

His focus on development and anti-corruption carried into later political ambitions. However, his youthful "independence" of party politics did not. Some years later Mahendra joined the BJP which came to prominence in Uttarakhand after this research was completed. He went on to contest an MLA seat in a nearby constituency but lost to a member of the Congress Party. He ran on a platform of "striving" and "development" "without fear and without corruption." His friend in the student union, who used to speak against party politics, also eventually joined the BJP and won a local position in Nainital. The student leader of a previous generation with whom they associated, later joined the Congress Party that he had vocally critiqued. However, all tried to maintain their platform of anti-corruption, and all cited their legacy in student politics as part of their credentials.

\title{
A "Pure" Vote?
}

To be regionally charismatic was, in the particular narratives of student leaders I met, to rise above dirty politics. Discussions of respect and "purity" in politics circulated in

South Asia Multidisciplinary Academic Journal, 22 | 2019 
various print media outlets and youth cultural production in Nainital. The student yearbooks and campus newspapers for Kumaun University contained multiple poems and essays written in Hindi, and I offer one small example from the Nainital Campus Reporter:

Interviewer: In today's student politics, without pamphlets, without posters, without chicken, rather, with only a speech, it's a miracle to get more than a hundred votes!

Student leader: I have full faith that there is still some immāndārì (respect) left in the student body- those 418 votes were pavitrā (pure)!

A "pure" vote was seen as one that came from the heart rather than being bought or manipulated. This moral orientation in student politics (Jeffrey 2009; Kumar 2012) animated regional charisma, and its mobilization was a way to overcome the corrupt image of political leaders and state failures and gain supporters through emotive and aspirational means. Werbner and Basu (2002) argue for an understanding of charisma as a moral aptitude in postcolonial contexts where "it is often the opposition between a morally grounded charisma and the rationalized authority of the state" (p.15). When student leaders make "representative claims" (Saward 2010) to a body of local or regional youth, such claims can often occur "outside the electoral process" (Tawa Lama-Rewal 2016:169) of larger party politics, as they find ways to seek legitimacy away from perceived corruption.

Regional charisma confers an aura of legitimacy and enchantment to political figures engaged in what has been described as the "(im)morality" (Osella 2014) of localized clientelism and brokerage in India (see also Alm 2012; Nielsen 2012; Jeffrey 2009; Tanabe 2007). While appearing as polarized ways of generating legitimacy (charisma is often seen as "magical" and spontaneous while brokerage involves earthy types of material exchanges), both are sutured qualities in the making of regional leaders. "Vote-buying," as Björkman (2014) has productively shown, often works through meaningful types of reciprocity and gift-giving (Mauss 1966). Such exchanges are "constitutive of enduring networks of trust, sociality, and accountability" and "signal access" that leaders have to various kinds of know-how and resources (Björkman 2014:618). Often leaders in India offer hand-outs because of competing expectations to do so in elections (Chauchard 2018), and yet such leaders see their "choice" being "not instrumental, but distinctly moral" as they imagine their "obligations" and relationships (Piliavsky 2014: 155). Gorringe (2012) argues that charisma "cannot perform the daily work on which movement allegiance depends" (p.122), yet competence and charisma are sutured in the quest for legitimation and "even hereditary leaders have few followers when they lack charisma and skill" (Mines and Gourishankar 1990:762). Without this regional charisma, such types of exchanges and use of know-how become more easily mundane and corrupt, rather than almost extraordinary and special.

When Mahendra narrated his election process, he seemed proud of the affection of his supporters and his ability to be a peacemaker. At the time of nomination, he said, another leader's supporters were also marching on the road. A fist-fight then broke out between the supporters, and the police had to come and separate the groups. The proctor arrived, and in front of him Mahendra allegedly proclaimed, "OK, we won't fight!" He explained to me, "When there is a large crowd, people get emotional. People are ready to fight. They fight for me." Emotions such as anger, frustration or love 
underlie the substance of "mobilizing structures" and "opportunities" for youth (Goodwin, Jasper and Poletta 2001) and thus helped to generate charismatic affect. Morality and anger could thus be interlinked in such demonstrations (Jaoul 2008), and a leader's ability to manage the emotions of others also added to their charismatic affect. Mahendra was aware that his samārtak (supporters) had different ambitions, and his efforts to gain supporters show the contradictions and failures in generating charisma. Many had faith in and devotion for him, he claimed, often due to the sacrifices he made, and his group seemed to share a sense of familiarity and affection (see also Ruud 2010). One the one hand, he explained:

M: When my posters came from the printers, I gave them to all my good supporters who didn't want money and gifts from me. They used to even go out at night in winters. They used to write on roads, paint, put up my posters and other things.

LK: Yes. I can still see them around town.

M: So, it was like that. They had a passion to make me a winner at any cost.

However, he also had others with him who "were supporting someone else and partying on my money" he said. Many knew that their supporters were self-interested, but they needed their help to get things done. Students tried to develop a youthful regional charisma in order to overcome the negative association with political corruption and self-interested support as well as to show themselves as more than "ordinary."

Mahendra also reasoned that public expectations were misplaced, and he attempted to manage multiple means of gaining support. For example, he set up coaching classes and free lectures by well-known professors and historians on the campus. However, many students did not come, he surmised, partly because they did not trust the intentions of leaders:

We have this problem here. People think that the leader does not want to do anything for them, but it's not like that. I know that I worked hard for this campus, I did a lot of things, but people also don't want to accept good things. They just want their personal benefits from me. They don't care about those things which are beneficial for everyone.

Like many of the leaders with whom I socialized, Mahendra often stressed that he wanted to fight the corruption in the state that was preventing proper development and employment opportunities from taking place; in speeches he decried the lack of progress on the part of politicians. Similar to the activist-politician in Nielsen's (2012) account, Mahendra also posed himself as fighting the "system":

I came into student politics when I saw our system. I wanted to be an IAS (Indian Administrative Service) Officer... but when I began college, I become aware of all kinds of issues. Then I felt that it's not enough to be an IAS officer. To change the system, I joined politics.

\section{On Knowledge and Information in Student Politics}

In demarcating a relationship between charisma and know-how-having or possessing knowledge and access to spaces that "ordinary" people do not have-I draw from what Hansen and Verkaaik (2009) refer to as "the magicality of these connections" (p.16; See 
also Jensen 2009). In speeches and conversation leaders employed the Hindi terms jānkāri and jñān to indicate knowledge that comes from special institutionalized learning or through particular kinds of experience and the term sūcnā usually when discussing "information." Such language saturated their speeches and assertions: knowledge of the town and campus; how to get a job; which subjects of study to choose; how to make social connections in order to get ahead.

I refer to another charismatic Pahari Rajput student leader in a hill town in Garhwal, "Mohan." He grew his hair long and was well-groomed, often dressed in pleated dress pants and shiny shoes, and exuded a calm confidence. When we first met, he gave me a tour of the campus, and students kept coming up to him to ask him questions or show him their papers. As we walked, he stressed that his main goal was to help other students to find employment, especially those coming from nearby villages. The students were lacking in sucnā-sūcnā (information) on how to navigate the new social spaces and the bureaucratic knots of the university and the town, he stressed. Mohan also used the term jānkāri (knowledge) as something he wanted to help students obtain from their studies. He emphasized:

Politics koī job nahìm hai (Politics is not a job). The meaning of politics is to live in samāj (society) and show people the diśa (way). Whatever field I join, I want to be able to give some time to the community...Because when I was in student politics I saw students' dukh (troubles). I got quite a lot of anubhāv (experience) from the student union election...I obtained direct contact with the administration and secretariat. I want to give that $f \bar{a} y d \bar{a}$ (benefit) to the local students.

When asked about his aspirations, he claimed that after the year of service in the union, one gains pahacān (recognition). "What you learn in that one year, you cannot learn in your entire lifetime... No $\bar{a} m \bar{a} d m \bar{\imath}$ (ordinary person) could obtain the jñān (knowledge) that we gain thinking about student problems while President." In particular, he claimed that youth of the new generation had a unique know-how that their elders could not possess. But to gain such knowledge, one had to be extraordinary.

Like Mohan, Mahendra also used his know-how strategically during his campaign. While I could not confirm many of the events that he described from his past, the fact that he unabashedly shared such behaviors as a "natural" part of politics, couching them in his perceived likability, is what is of interest here. He told me an interesting story about his election that reveals his efforts:

M: Girls started liking me. They started supporting me and said they will promote me. Then the election took place...When I went to meet them for the first time, they said to me 'Neta ji! How did you come without bringing us anything?' I said, 'Next time I come, tell me your demands.' They said, 'It's OK, next time you can bring things; this time get us some cold drinks and some patties [a type of food snack] for us.' I gave money to my supporters and told them to bring these things.

LK: You mean you will have to give them something so that they will put your posters up on the walls?

M: No, no, I am not talking about posters. I went to ask for votes. Even girls demanded beer bottles and chicken. They told me that they wanted beer and chicken. They said, 'Without that we can't vote for you.' 
I naively thought I had misheard him. Especially in this part of India, many local young women would avoid being caught drinking. He clarified:

M: No, girls... they were serious- they wanted me to treat them before the election. I arranged drinks for them. Then they said, 'If we come and vote, you will have to send a bus for us. We will vote then roam around town, and then your bus will drop us back.' I did that. proving his abilities with exceptional ease, because he could employ his knowledge of the town's rhythms and spaces and use his local connections. As Björkman (2014) writes about vote-banking in Mumbai, such exchanges "index 'accomplished power" ((Parmentier 2002:65) as cited in Björkman 2014:629) and instantiate "the networks of knowledge, authority, and resources that are crucially necessary for navigating" the spaces of the city or town (p.631). Mahendra helped the girls by allowing them a way to party freely, and also ensured their safety while they went out to socialize in the evening. This was a valuable favor; the girls' hostels were built up high-up, off winding, forested, unlit roads that became dark early in the evenings, and they had to walk a long distance uphill in order to arrive before curfew. It was more socially acceptable for men to socialize and roam around after dark, and many of those out late at night were actually thought to be afflicted with alcoholism, a politically emotive issue in the region. The young women must have felt comfortable asking for help to privately engage in publicly less-approved practices. His offering of security for local women reveals how the cultivation of this particular elaboration of charisma worked through masculine cultural tropes, such as his attempt to take on a gendered "protective" role that not just anyone could have accessed. and guide; they had special knowledge of how to navigate social worlds in the town, such as the university campus, municipal offices, hospitals and their bureaucracies, as well as the streets, marketplaces, and other public arenas. A phone call could help a family member get seen at the hospital more quickly, a meeting could help young women deal with harassment, and a request could help a student gain admission at the university. Such information and connectivity helped many young people in Uttarakhand in a time of economic uncertainty. Taking advantage of his "networking" ability, Mahendra worked to show himself as important. Such brokerage and transactions could not be delivered by just anyone, even with connections. In the context of Uttarakhand and the spaces of emotional, aspirational struggles for "futures," having the awareness of the unknown (or seemingly inaccessible) spaces of the town and its histories helped to build the overall charismatic influence of young leaders.

\section{Conclusions}

These stories of political self-making elicit questions regarding whether or not student leaders were successful at being a "truly" charismatic leader in a broad sense. Often relying on brokerage or fights, Mahendra also wanted to craft an image of Pahari morality, innocence and selflessness. The desire to be charismatic is one that touches on youth aspirations in the region itself. The notion of regional charisma moves beyond helpful, but static, Weberian definitions of leadership, instead opening up

South Asia Multidisciplinary Academic Journal, 22 | 2019 
opportunities to show the powerful regional and place-made variants of generating and inspiring support on smaller and more intimate scales. Mahendra inspired devotion in some and was used by others. He relied on transactional relationships, and yet had a "magical" connection to the town, which attracted people to approach him. As even the most mystical of leaders have to continuously maintain the aura of their natural abilities, in this way charisma is unmasked as a mode of self-fashioning. Charismatic hill town politics develop through localized aspirations and reterritorialized cosmopolitan associations, family legacies, gendered performative displays of knowhow and sacrifice, and even caste affiliations or privileges. Charisma can be mobilized as a form of dissent yet can also reproduce political and social hierarchies, as the cases of Mahendra, Mohan and others show. Drawing from their family associations and privileges, forward caste young men could mobilize belonging not only through regional identities, but through caste affiliations, youthful distance from corrupt adult party politics, and stylized and masculine political performances.

While this article has described the production of regional charisma in the making of student leaders in Uttarakhand, underneath this it attempts to reconcile the contradictions between experiential knowledge and political genealogies with that of newness and youthful ambition. Such knowledge is relayed through earlier generations and authority figures, but yet is refashioned in a youthful politics of the contemporary. Student politics often confronts the state, which is made up of those who have grown out of youthful ideals, and which fails to uphold the promises of "development." Yet in their efforts to expand their experiential horizons, youth imagine what a charismatic leader should be. As student politicians begin to retreat from older generations of leaders and from the state as a steward of rights, a new generation rely on and remake charismatic repertoires as they seek support and attempt to carve out a future in the region.

\section{BIBLIOGRAPHY}

Alm. Björn. 2010. "Creating Followers, Gaining Patrons: Leadership Strategies in a Tamil Nadu Village." Pp.1-19 in Power and Influence in India: Bosses, Lords and Captains edited by A.E. Ruud and P. Price. London: Routledge.

Björkman, Lisa. 2014. “'You Can't Buy a Vote': Meanings of Money in a Mumbai Election.” American Ethnologist 41(4):617-634.

Brown, Trent, Timothy J. Scrase and Ruchira Ganguly-Scrase. 2017. "Globalised Dreams, Local Constraints: Migration and Youth Aspirations in an Indian Regional Town." Children's Geographies 15(5):531-544.

Chandra, Uday and Atreyee Majumder. 2013. "Introduction. Selves and Society in Postcolonial India." South Asia Multidisciplinary Academic Journal [SAMAJ] 7:1-16.

Chakrabarty, Dipesh. 2002. "Khadi and the Political Man." Pp. 51-64 in Habitations of Modernity: Essays in the Wake of Subaltern Studies by Dipesh Chakrabarty. Chicago: University of Chicago Press. 
Chakraborty, Ritodhi. 2018. The Invisible (Mountain) Man: Migrant Youth and Relational Vulnerability in the Indian Himalayas. PhD dissertation, Department of Geography, University of Wisconsin.

Chauchard, Simon. 2018. "Electoral Handouts in Mumbai Elections: The Cost of Political Competition." Asian Survey 58(2):341-364.

Cole, Jennifer. 2004. "Fresh Contact in Tamatave, Madagascar: Sex, Money, and Intergenerational Transformation.” American Ethnologist 31(4):573-88.

De Certeau, Michel. 1988. The Practice of Everyday Life. (Translated by S. Rendall). Berkeley: University of California Press.

Deuchar, Andrew. 2019. "Strategically 'Out of Place': Unemployed Migrants Mobilizing Rural and Urban Identities in North India." Annals of the American Association of Geographers 1-15.

Dickey, Sara. 1993. "The Politics of Adulation: Cinema and the Production of Politicians in South India." The Journal of Asian Studies 52(2):340-372.

Eckert, Julia M. 2003. The Charisma of Direct Action: Power, Politics, and the Shiv Sena. New York; New Delhi: Oxford University Press.

Fiol, Stefan. 2013. "Of Lack and Loss: Assessing Cultural and Musical Poverty in Uttarakhand." Yearbook for Traditional Music (45):83-96.

Forbess, Alice, and Lucia Michelutti. 2013. "From the Mouth of God: Divine Kinship and Popular Democratic Politics. Focaal (67):3-18.

Fuh, Divine. 2012. “The Prestige Economy: Veteran Clubs and Young Men's Competition in Bamenda, Cameroon." Urban Forum 23(4):501-526.

Geertz, Clifford. [1983] 2000. "Centers, Kings, and Charisma: Reflections on the Symbolics of Power." Pp. 121-146 in Local Knowledge: Further Essays in Interpretive Anthropology. New York: Basic Books.

Goodwin, Jeff, James M. Jasper, and Francesca Polletta. 2001. "Introduction: Why Emotions Matter." Pp. 1-27 in Passionate Politics: Emotions and Social Movements, edited by J. Goodwin, J.M. Jasper, and F. Polletta. Chicago: University of Chicago Press.

Gorringe, Hugo. 2005. Untouchable Citizens: Dalit Movements and Democratisation in Tamil Nadu. Thousand Oaks, California; New Delhi: Sage Publications.

Gorringe, Hugo. 2010. “The New Caste Headmen? Dalit Movement Leadership in Tamil Nadu.” Pp. 119-143 in Power and Influence in India: Bosses, Lords and Captains, edited by A. E. Ruud and P. Price. London: Routledge.

Guha, Ramachandra. 2000. The Unquiet Woods: Ecological Change and Peasant Resistance in the Himalaya. Berkeley: University of California Press.

Gururani, Shubra. 2014. “'Geographies that Make Resistance': Remapping the Politics of Gender and Place in Uttarakhand, India." HIMALAYA, the Journal of the Association for Nepal and Himalayan Studies 34(1)12:68-79.

Hansen, Thomas Blom and Oskar Verkaaik. 2009. "Introduction- Urban Charisma: On Everyday Mythologies in the City." Critique of Anthropology 29(1):5-26.

Hebdige, Dick. 1988. Subculture: The Meaning of Style. London: New Accents, Routledge.

Jaoul, Nicolas. 2008. “The 'Righteous Anger' of the Powerless: Investigating Dalit Outrage over Caste Violence." South Asia Multidisciplinary Academic Journal [SAMAJ] 2:1-32. 
Jeffrey, Craig. 2009. "Fixing Futures: Educated Unemployment through a North Indian Lens." Comparative Studies in Society and History 51(1):182-211.

Jeffrey, Craig. 2010a. Timepass: Youth, Class, and the Politics of Waiting in India. Stanford, CA: Stanford University Press.

Jeffrey, Craig. 2010b. "Contradictory Youth Politics: Student Mobilisation in Uttar Pradesh." Pp. 96-118 in Power and Influence in India: Bosses, Lords and Captains, edited by A. E. Ruud and P. Price. London: Routledge.

Jeffrey, Craig, and Jane Dyson. 2014. “'I serve therefore I am': Youth and Generative Politics in India." Comparative Studies in Society and History 56(4):967-994.

Jeffrey, Craig, Patricia Jeffery and Roger Jeffery. 2008. Degrees Without Freedom? Education, Masculinities, and Unemployment in North India. Stanford: Stanford University Press.

Jensen, Steffen. 2009. "Gendered Connections: Politics, Brokers and Urban Transformation in Cape Town." Critique of Anthropology 29(1):47-64.

Joshi, Bhoomika. 2015. "Memes of Mobility and Socio-spatial Transformation: 'Drivery' in Uttarakhand." Economic and Political Weekly 50(1):17-21.

Joshi, Bhoomika. 2018. "Uttarakhand, an Intriguing Case of Hindutva Politics." South Asia Monitor. Retrieved on October 14, 2019 (https://southasiamonitor.org/news/uttarakhand-an-intriguingcase-of-hindutva-politics/open-forum/27757)

Kadir, Hatib A. 2012. "School Gangs of Yogyakarta: Mass Fighting Strategies and Masculine Charisma in the City of Students. The Asia Pacific Journal of Anthropology 13(4):352-65.

Klenk, Rebecca M. 2010. Educating Activists: Development and Gender in the Making of Modern Gandhians. Lanham, MD: Rowman \& Littlefield Publishers.

Koskimaki, Leah. 2011. Youth Publics and Embodied Politics: Genealogies of Development Aspiration in North Indian Hill Towns. PhD Dissertation, Department of Anthropology, University of Washington.

Koskimaki, Leah. 2015. “Addressing the Youth: Emerging Youth Publics in Late Colonial Uttarakhand." Himalaya, the Journal of the Association for Nepal and Himalayan Studies 35(2):41-55.

Koskimaki, Leah. 2017. "Youth Futures and a Masculine Development Ethos in the Regional Story of Uttarakhand." Journal of South Asian Development 12(2):136-54.

Krishna, Anirudh. 2003. "What is Happening to Caste? A View from Some North Indian Villages. The Journal of Asian Studies 62(4):1171-93.

Kumar, Anup. 2011. The Making of a Small State: Populist Social Mobilisation and the Hindi Press in the Uttarakhand Movement. New Delhi: Orient Blackswan.

Kumar, Pradeep. 2000. The Uttarakhand Movement: Construction of a Regional Identity. New Delhi: Kanishka Publishers.

Kumar, Satendra. 2012. "Ethnography of Youth Politics: Leaders, Brokers and Morality in a Provincial University in Western Uttar Pradesh." History and Sociology of South Asia 6(1):41-70.

Kumar, Satendra. 2017. "Hero.” South Asia: Journal of South Asian Studies 40(2):327-329.

Linkenbach, Antje. 2006. "Nature and Politics: The Case of Uttarakhand, North India." Pp. 151-169 in Ecological Nationalisms: Nature, Livelihoods, and Identities in South Asia, edited by G. Cederlof and K. Sivaramakrishnan. Seattle, WA: University of Washington Press. 
Ritty A. Lukose. 2009. Liberalization's Children: Gender, Youth, and Consumer Citizenship in Globalizing India. Durham: Duke University Press.

Mamgain, Rajendra P., and Reddy, Duv Narasimha. 2016. "Out-migration from the Hill Region of Uttarakhand: Magnitude, Challenges and Policy Options." Lucknow: Giri Institute of Development Studies, Working Paper No. 218. Retrieved on October 14, 2019 (https://www.researchgate.net/ publication/321054929_Outmigration_from_the_Hill_Region_of_Uttarakhand_Magnitude_Challenges_and_Policy_Options) Mannheim, Karl. [1936] 1972. “The Problem of Generations.” Pp. 101-138 In The New Pilgrims: Youth Protest in Transition, edited by P. Altbach \& R. Laufer. New York: David McKay.

Martelli, Jean-Thomas and Barış Arı. 2018. "From One Participant Cohort to Another: Surveying Inter-generational Political Incubation in an Indian University." India Review 17(3):263-300.

Martelli, Jean-Thomas. "The Politics of Our Selves: Left Self-fashioning and the Production of Representative Claims in Everyday Indian Campus Politics." Modern Asian Studies. Under Review.

Mathur, Nayanika. 2015. “A Remote Town in the Indian Himalaya." Modern Asian Studies 49(2): 365-392.

Mathur, Nayanika. 2016. Paper Tiger: Law, Bureaucracy and the Developmental State in Himalayan India. Delhi: Cambridge University Press.

Mawdsley, Emma. 1996. "Uttarakhand Agitation and Other Backward Classes." Economic and Political Weekly 31(4):205-10.

Mawdsley, Emma. 1998. “After Chipko: From Environment to Region in Uttaranchal.” The Journal of Peasant Studies 25(4):36-54.

Mawdsley, Emma. 1999. “A New Himalayan State in India: Popular Perceptions of Regionalism, Politics, and Development.” Mountain Research and Development 19(2):101- 112.

Mazzarella, William. 2010. "Branding the Mahatma: The Untimely Provocation of Gandhian Publicity.” Cultural Anthropology 25(1):1-39.

Michelutti, Lucia. 2018. "Parivar Raj (Rule of Family): The Role of Money and Force in the Making of Dynastic Authority." Studies in Indian Politics 6(2):196-208.

Michelutti, Lucia. 2017. "We are all Chávez: Charisma as an Embodied Experience." Latin American Perspectives 44(1):232-50.

Michelutti, Lucia. 2013. "Sons of Krishna and Sons of Bolivar: Charismatic Kinship and Leadership across India and Venezuela." Focaal (67):19-31.

Michelutti, Lucia. 2010. "Wrestling with (Body) Politics: Understanding 'Goonda' Political Styles in North India.” Pp. 44-69 in Power and Influence in India: Bosses, Lords and Captains, edited by A. E. Ruud and P. Price. London: Routledge.

Mines, Mattison and Vijayalakshmi Gourishankar. 1990. "Leadership and Individuality in South Asia: The Case of the South Indian Big-Man.” The Journal of Asian Studies 49(4):761-786.

Moller, Joanne. 2000. "Anti-reservation Protests and the Uttarakhand Pro-autonomy Movement: Caste and Regional Identities in the Indian Himalayas." South Asia Research 20(2):147-169.

Nielsen, Kenneth Bo. 2012. “'An Activist Can't Become a Politician': Social Activism, Leadership and the (Un)Making of a Political Career in an Indian State." Contemporary South Asia 20(4): 435-453. 
Osella, Filippo. 2014. “The (Im)morality of Mediation and Patronage.” Pp. 365-393 in Patronage as Politics in South Asia, edited by A. Piliavsky. New York: Cambridge University Press.

Pathak, Shekhar. 1997. "State, Society and Natural Resources in Himalaya: Dynamics of Change in Colonial and Post-colonial Uttarakhand.” Economic and Political Weekly 32(17):908-912.

Piliavsky, Anastasia. 2014. “India's Demotic Democracy and its 'Depravities' in the Ethnographic Long Durée." Pp. 154-175 in Patronage as Politics in South Asia, edited by A. Piliavsky. New York: Cambridge University Press.

Pradhan, Queeny. 2017. Empire in the Hills: Simla, Darjeeling, Ootacamund, and Mount Abu, 1820-1920. New Delhi: Oxford University Press.

Rancière, Jacques. 2004. “Introducing Disagreement.” Angelaki 9(3):3-9.

Rancière, Jacques. 1999. Disagreement: Politics and Philosophy. Minneapolis: University of Minnesota Press.

Rangan, Haripriya. 1996. "From Chipko to Uttaranchal: Development, Environment, and Social Protest in the Garhwal Himalayas, India." Pp. 205-26 in Liberation Ecologies: Environment, Development, Social movements, edited by R. Peet and M. Watts. London; New York: Routledge. Rangan, Haripriya 2000. Of Myths and Movements: Rewriting Chipko into Himalayan History. New York; London: Verso.

Rudolph, Lloyd I. and Susanne Hoeber Rudolph. 1967. The Modernity of Tradition: Political Development in India. University of Chicago Press, Chicago.

Ruud, Arild E., and Pamela Price. 2010. "Introduction." Pp 20 -34 in Power and Influence in India: Bosses, Lords and Captains, edited by A. E. Ruud and P. Price. London: Routledge.

Ruud, Arild E. 2010. “To Create a Crowd: Student Leaders in Dhaka.” Pp. 70-95 in Power and Influence in India: Bosses, Lords and Captains, edited by A. E. Ruud and P. Price. London: Routledge. Saward, Michael. 2010. The Representative Claim. New York; Oxford: Oxford University Press. Sivaramakrishnan, K. 1995. "Colonialism and Forestry in India: Imagining the Past in Present Politics." Comparative Studies in Society and History 37(1):3-40.

Skaria, Ajay. "Gandhi's Politics: Liberalism and the Question of the Ashram." South Atlantic Quarterly 101(4):955-986.

Suykens, Bert. 2018. “'A Hundred Per Cent Good Man Cannot Do Politics': Violent Self-Sacrifice, Student Authority, and Party-State Integration in Bangladesh." Modern Asian Studies 52(3):883916.

Tanabe, Akio. 2007. “Toward Vernacular Democracy: Moral Society and Post-Postcolonial Transformation in Rural Orissa, India." American Ethnologist 34(3):558-574.

Tarlo, Emma. 1996. Clothing Matters: Dress and Identity in India. Chicago: University of Chicago Press.

Tawa Lama-Rewal, Stéphanie. 2016. “Political Representation in India: Enlarging the Perspective." India Review 15(2):163-71.

Tillin, Louise. 2013. Remapping India: New States and their Political Origins. New York; Oxford: Oxford University Press.

Trivedi, Lisa. 2007. Clothing Gandhi's Nation: Homespun and Modern India. Bloomington: Indiana University Press. 
Verstappen, Sanderien. 2017. "Mobility and the Region: Pathways of Travel within and beyond Central Gujarat. Journal of South Asian Development 12(2):112-35.

Weber, Max. [1919] 2009. "Politics as a Vocation.” Pp. 77-178 in From Max Weber: Essays in Sociology, edited by H. H. Gerth and C. W. Mills. London: Routledge.

Werbner, Pnina and Helene Basu, 2002. "The Embodiment of Charisma." Pp 1-27 in Embodying Charisma: Modernity, Locality, and Performance of Emotion in Sufi Cults, edited by P. Werbner and $\mathrm{H}$. Basu. London; New York: Routledge.

Weiss, Brad. 2005. "The Barber in Pain: Consciousness, Affliction and Alterity in Urban East Africa." Pp. 102-120 in Makers and Breakers: Children and Youth in Postcolonial Africa, edited by A. M. Honwana and F. de Boeck. Trenton, NJ: Africa World Press.

Wood, Bronwyn. E. 2012. “Crafted within Liminal Spaces: Young People's Everyday Politics. Political Geography 31(6):337-346.

\section{NOTES}

1. The research for this paper was supported by a Fulbright-Hays DDRA grant. I thank JeanThomas Martelli, Kristina Garalyté, Stéphanie Tawa Lama-Rewal, Bhoomika Joshi and three anonymous reviewers for their insightful comments. I am grateful to K. Sivaramakrishnan and Danny Hoffman for their input and support when I was first putting this research to paper, and Anand Pandian and Devika Bordia who offered valuable comments when I presented an earlier version of this paper at the Annual Conference on South Asia at Madison. I thank colleagues in Department of Anthropology where I presented this work at the University of the Western Cape, and to the participants of the workshop for this special issue, for their stimulating comments and discussions. All errors in this paper are my own.

2. Kumaun University was formed in 1973 after a student demand, with the Nainital DSB campus named after Dev Singh Bisht, the father of Dan Singh Bisht, a $20^{\text {th }}$ century Kumauni businessman and timber magnate who supported the building of the DSB Government College, which preceded the formation of the university.

3. Abhishek Bachchan and Hrithik Roshan were some of the most popular, young, leading male film stars in Bollywood at the time.

4. Cinema culture has often been intertwined with politics in India, in what Dickey (1993) has called a "politics of adulation." Popular actors play heroes on screen, and some even later dabble in party politics, drawing from their fame and support.

5. Pahari means of the mountains or hills, derived from the Hindi work pahār, or mountain, and is used to reference people living there.

6. My methodology involved participant-observation, meetings with youth and student groups, interviews with older generations of activists and regional leaders, attendance of rallies and collection of print media such as Hindi language newspapers, magazines, campus journals and yearbooks, student posters and pamphlets. The research covered a wide range of youth engagement, from NGO workers in rural areas to activist journalists of different generations in hill towns in both Kumaun and Garhwal. Within this field of public engagement, I included a look into contemporary hill town student politics in Nainital as well as a few selected hill towns.

7. See also Cole 2004; Wood 2012; and Jeffrey 2010 b on the role of liminality in youth engagement. 8. See for example, Eckert (2003:86) on the charisma of Bal Thackeray, the staunch nativist Marathi regional leader of the political party, Shiv Sena, in Mumbai. 


\section{ABSTRACTS}

This article explores the production of "regional charisma" in youth politics in hill towns of Uttarakhand, India. Focusing largely on the narratives and experiences of a group of forward caste student leaders in the hills in the years after statehood (November 2000), the article offers an ethnography of political aspiration. Student leaders worked to cultivate regional charisma through drawing on their caste affiliations and political genealogies, demonstrating localized knowledge, and referring to regional idioms of place. They fashioned themselves as appealing and caring moral leaders, orienting their political practices toward sacrifice and service, while disassociating themselves from perceived corruption in adult party politics. In this way, the article argues that regional charisma is a quality that is sutured in, rather than contradictory to, transactional political repertoires.

\section{INDEX}

Keywords: student politics, youth, charisma, clientelism, self-fashioning, regionalism, morality, Uttarakhand

\section{AUTHOR}

\section{LEAH KOSKIMAKI}

University of the Western Cape 